\title{
Selvmordsrisiko og -forebygging under covid-19-pandemien og etterpå
}

\author{
Av Ping Qin, Ingunn Legard, Fredrik A. Walby, Anita Johanna Tormoen og Lars Mehlum
}

\author{
Covid-19-pandemien vil trolig ha omfattende og langvarige \\ effekter på psykisk helse i befolkningen, og en økning i \\ forekomst av selvmord og villet egenskade kan bli en \\ konsekvens. Det er behov for økt oppmerksomhet rettet \\ mot selvmordsforebygging.
}

KORONAVIRUSET HAR VART gienstand for global oppmerksomhet og frykt siden januar i år og hittil har viruset smittet over 4,5 millioner mennesker og ført til over 300 ooo bekreftede dødsfall. I Norge ble forste smittetilfelle registrert 25 . februar og utbruddet har resultert i 232 dødsfall og 8172 smittede offisielt rapportert per 12. mai 2020 (Folkehelseinstituttet, 2020). For å stoppe spredningen av viruset er en rekke unike tiltak iverksatt i Norge og i store deler av verden. Den 12. mars bestemte norske myndigheter seg for å stenge barnehager, skoler og arbeidsplasser, begrense reiser og oppfordre folk til å holde seg hiemme. Dette er tiltak som går under betegnelsen «sosial distansering» med mål om å begrense kontakt mellom mennesker. Tiltakenes positive effekt på smittespredningen har ført til oppmykning eller oppheving av noen av tiltakene, men mange av tiltakene må opprettholdes over lengre tid og dette kan potensielt ha stor innvirkning på selvmordsrisiko.

\section{Psykologiske konsekvenser}

Studier har påvist klare negative effekter på psykisk helse etter naturkatastrofer som orkaner, flom og jordskjelv, og liknende psykologiske konsekvenser kan oppstå etter en pandemi (Douglas et al., 2009). Flere studier etter epidemiene knyttet til SARS, MERS og svineinfluensa har vist en høy forekomst av posttraumatisk stresslidelse (PTSD) og depresjon hos personer i karantene (Sim \& Chua, 2004) og en okt risiko for langvarige psykiske problemer hos overlevende og helsepersonell (Lee et al., 2018). Under den nåværende pandemien har flere studier publisert de siste ukene vist et høyt nivå av stressrelaterte symptomer som depresion, angst, søvnløshet hos medisinsk personell, pasienter og personer i karantene (Lai et al., 2020; Bo et al., 2020; Sani et al., 2020).

Både pandemien og tiltakene som iverksettes for å begrense smittespredning, forer til en sterkt endret hverdag for de fleste med separasion fra familie og nære og fare for sosial isolasjon. For mange har det ført til tap av arbeid og inntekt. På individuelt nivå kan det føre til økt stress og frykt og symptomer som angst, depresion eller søvnvansker. Disse psykiske reaksjonene vil trolig vare en stund etter at virusets spredning er stoppet. På lengre sikt kan pandemiens uheldige ettervirkninger manifestere seg som $ø$ kt forekomst av psykiske lidelser i befolkning og eventuelt selvmord i risikoutsatte grupper. Dette har vi foreløpig lite sikker viten om. 


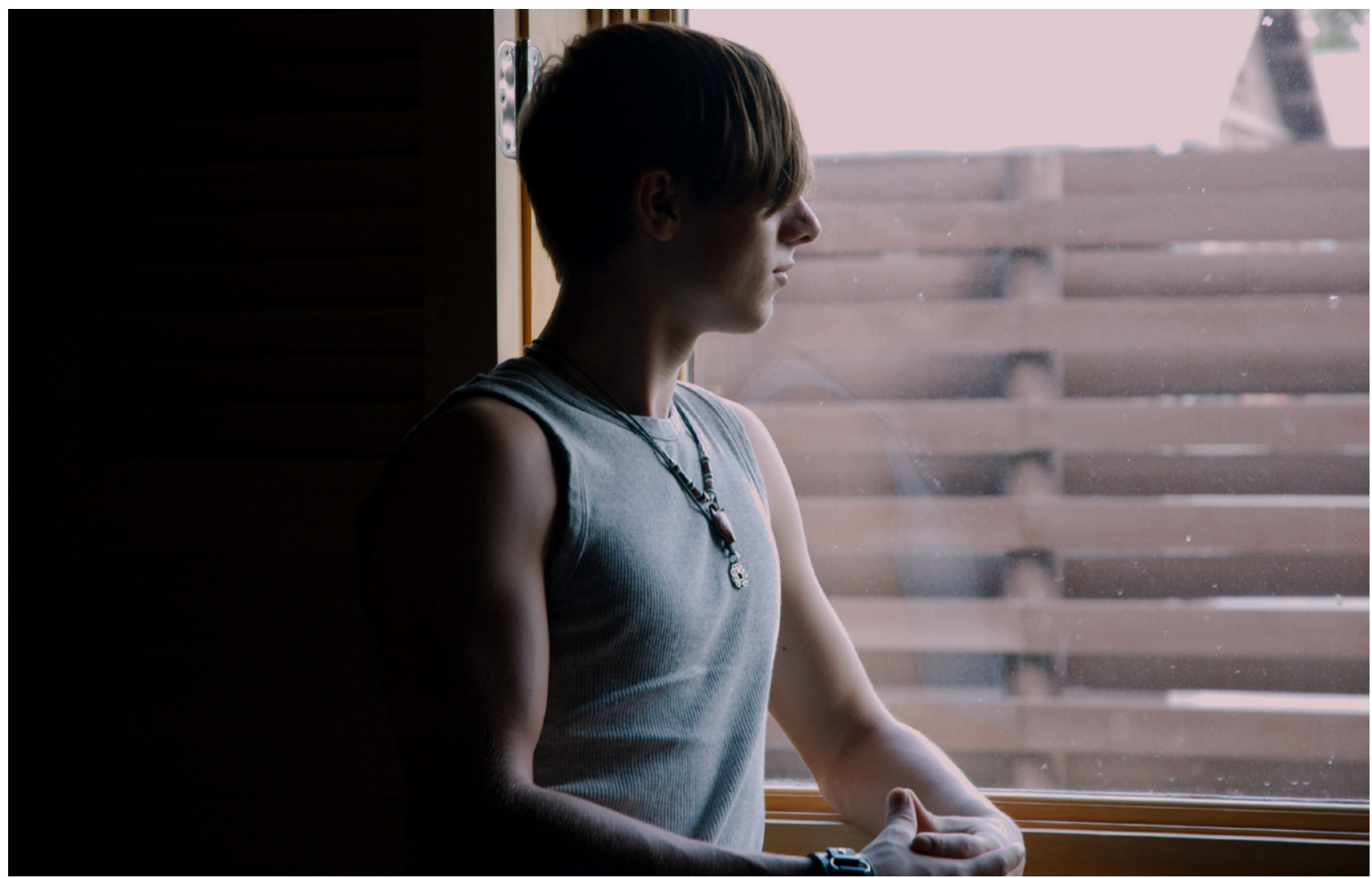

\section{Risiko for selvmordsatferd}

Årsakene til selvmordsatferd er sammensatte og ofte et resultat av samspill mellom ulike faktorer av psykologisk, sosial og biologisk karakter. Psykiske lidelser, særlig depresion, rus- og avhengighetslidelser, PTSD, angst og personlighetsforstyrrelser er viktige individuelle risikofaktorer for selvmordsatferd. De fleste andre kiente risikofaktorer for selvmordsatferd har det til felles at individet opplever en taps- eller konfliktsituasjon med store konsekvenser for fremtiden. Det kan dreie seg om tap og brudd i nære relasioner, tap av arbeid og inntekt, eller tap av selvaktelse, trygghet og identitet. Covid19-pandemien medfører at mange utsettes for uventede og vesentlige tap. Avhengig av hvordan disse tapene takles kan risikoen for selvmordsatferd oke. Tidligere studier har vist en $ø$ kt selvmordsrate under spanskesyken i USA i 1918-1919 (Wasserman, 1992) og blant eldre i Hong Kong under SARS-epidemien i 2003 (Yip et al., 2010). Men omfattende krisesituasjoner kan også medføre at sosialt samhold blant folk generelt øker under slike vanskelige tider, slik at personer som ellers er marginalisert i større grad kan bli inkludert og få mer sosial støtte. Mange kan også oppleve at livet får et annet fokus slik at tidligere vanskeligheter blir mindre presserende stilt overfor en ytre trussel. En slik bevisstgiøring på grunnleggende behov og verdier kan være til hielp for mange. Det er likevel viktig å være klar over at forekomsten av selvmord under og etter kriser kan både øke og avta samtidig, men i ulike befolkningssegmenter. Mens store grupper kanskie får en redusert risiko, kan sårbare grupper få økt risiko. Igien har vi lite sikker viten om hvilke effekter vi kan forvente.

\section{Personer med psykiske problemer}

Avhengig av forløpet av pandemien og dens materielle, sosiale og økonomiske konsekvenser, kan vi komme til å se en sterk økning i antall personer som utvikler symptomer på de lidelsene vi har nevnt ovenfor, med økt risiko for selvmord, selvmordsforsøk og selvskading som konsekvens. For personer som hadde psykiske plager før utbruddet kan økt stress og usikkerhet fore til økte psykiske plager og forverring av tilstanden. Samtidig vil tilgangen til hielp og behandling for personer som allerede har en kjent eller nyoppstått psykisk lidelse kunne være redusert. Mange sårbare personer kan komme til å nedprioritere eller unngå å kontakte tienestene fordi de er redde for smitte eller for å være til bry. Stigmaet ved å ha fått 
covid-19 skal heller ikke undervurderes som en mulig barriere for å søke hielp i visse grupper.

\section{Personer med problematisk bruk av alkohol og rusmidler}

I en tid preget av usikkerhet, stor arbeidsledighet, bekymring og sosial distansering er det grunn til å anta at alkohol- og rusbruk vil øke i befolkningen og flere vil kunne utvikle avhengighetslidelser. Đkt rusbruk kan øke risikoen for selvmord og selvskading på kort sikt, og også disponere for utvikling av avhengighet med alvorlige psykiske, fysiske samt sosiale konsekvenser, og på den måten øke risikoen for selvmord også på lang sikt. Et redusert behandlingstilbud vil kunne virke svært uheldig i en slik situasjon.

\section{Barn og unge}

Barn og unge kan ofte uttrykke følelser som frykt, angst og tristhet under en pandemi, og disse følelsene vil ikke nødvendigvis forsvinne raskt. Selvskading kan for noen være en metode for å håndtere stress og frykt (Lockwood et al., 2017). Tiltak for sosial distansering har fundamentalt endret barn og unges hverdagsliv. Unge tilbringer også mye tid på internett for digital læring og kommunikasjon med jevnaldrende. Đkt bruk av sosiale medier kan resultere i mindre ansikt-til-ansiktkommunikasjon, økt avhengighet av å bli sosialt bekreftet via «likes» og et behov for å være tilgiengelig hele tiden. Dette kan igien føre til søvnproblemer, noe som bekreftes i forskning på internettbruk blant unge (Alimoradi et al., 2019). Hjemmemiliøet til barn og unge kan også bli mer negativt enn ellers giennom okt forekomst av fysisk eller psykisk vold mellom personer i hiemmet. Siden skolene stengte har mange barn og unge kontaktet Alarmtelefonen for barn og unges døgnåpne tjenester - en dobling av antallet brukere sammenliknet med tilsvarende perioder tidligere (Fladberg, 2020). Okt psykososialt stress, redusert tilgang til fritidsaktiviteter og støtte fra det ordinære sosiale nettverket og økt brukstid på sosiale medier er særlig uheldige risikofaktorer for psykisk helse hos barn og unge.

\section{Arbeidsledige, permitterte og personer under utdanning}

Arbeidsledighet og økonomisk stress er velkjente risikofaktorer for selvmord og villet egenskade (Haw et al., 2015). Siden smitteverntiltak ble iverksatt har over 423500 nordmenn søkt dagpenger (per 12. mai), et tall som er nesten tre ganger så høyt som de årlige tallene for 2019 og 2018 (NAV, 2020). En stor andel av disse er permitterte og antallet kan øke i ukene som kommer. Høyst sannsynlig vil det for mange være vanskeligere å finne en jobb i en lang periode etter pandemien. Den høye arbeidsledigheten, okonomiske tap og frykt for å miste jobben kan gi psykiske problemer som depresjon, angst og økt rusbruk, som igien kan føre til økt selvmordsatferd både på kort og lang sikt.

Under tiltakene for å hindre smittespredning har alle utdanningsinstitusjoner enten redusert eller lagt om virksomheten, noe som kan komplisere fremdriften i utdanningsløp for mange unge. Problemer med å få tatt eksamen eller problemer med å klare utgifter til livsopphold når man er avskåret fra inntekter fra deltidsarbeid kan representere sterke belastninger, særlig for sårbare grupper og når det varer over lengre tid.

\section{Helsepersonell}

Covid-19-pandemien gir helsevesenet i Norge og alle andre land utfordringer i en skala og med en varighet som vi ikke tidligere har sett. Helsepersonell som er direkte involvert i diagnostikk og behandling av pasienter med covid-19 er i risiko for å utvikle psykisk stress og andre psykiske symptomer. En nylig studie fra Kina viser at en stor andel helsepersonell rapporterer symptomer på depresion (50,4\%), angst (44,6\%), søvnløshet (34,०\%) og stress $(71,5 \%)$ (Lai et al., 2020), noe som tilsvarer funnene under SARS- og MERS-epidemiene. Erfaringer fra andre land viser at helsepersonell kan komme i svært krevende situasjoner hvor både frykt for smitte og eget liv og opplevelse av hielpeløshet kombinert med svært stor arbeidsmengde kan være meget belastende.

\section{Aleneboende og sosialt isolerte}

Ensomhet og sosial isolasion er velkjente risikofaktor for utvikling av depresion og selvmordsatferd uavhengig av alder og kjønn (Calati et al., 2019; Erzen \& Çikrikci, 2018). Mange mennesker bor alene og kan føle seg spesielt ensomme under de nåværende forholdene. Eldre mennesker, spesielt de som er i isolasjon og de som har kognitive utfordringer/demens kan bli mer engstelige, stresset og tilbaketrukket under pandemien eller i karantene. Sosial distansering er viktig for å stoppe spredning av virus, men det har en potensielt skadelig effekt på personer som opplever seg ensomme. Samtidig kan økt sosial isolasjon hos allerede sosialt isolerte representere et «usynlig» problem man undervurderer betydningen av. 


\section{Innvandrere og flyktninger}

Pandemien kan ramme innvandrere og flyktninger hardt på mange måter. Psykiske problemer og selvmordsrisiko i dette segmentet av befolkningen påvirkes ikke bare av psykisk stress fremkalt av pandemien, men også av opprinnelseskultur og relativ sosial og økonomisk marginalisering fra majoritetsbefolkningen (Amin et al., 2019; Puzo et al., 2017). Vår forskning har tidligere vist at de fleste grupper i innvandrerbefolkningen i Norge har en lavere risiko for selvmord enn majoritetsbefolkningen (Puzo et al., 2017). Dette antar vi også vil gielde under de rådende forholdene. Men språklige og kulturelle barrierer kan komme til å medføre at noen grupper blir mer eksponert for smitte og får mindre tilgang på hjelpetiltak enn andre og det kan gi økt risiko for sekundærvirkninger som selvmordsatferd.

\section{Pårørende og etterlatte}

Et ukjent antall personer vil komme til å miste sine nærmeste i covid-19-pandemien. For mange vil det i tillegg være en påkjenning ikke å kunne være sammen med sine nære i sykdomsperioden og ikke kunne giennomføre rituelle handlinger som vi er vant til ved sorg. Avhengig av hvordan vi håndterer disse utfordringene over tid kan etterlatte komme til å representere en risikogruppe for psykiske lidelser, slik som komplisert sorg, depresion, avhengighetslidelser og selvmordsatferd.

\section{Hvilke muligheter har vi for å forebygge selvmord i denne situasjonen?}

Den nåværende situasjonen er unik og usikkerheten er stor med tanke på hva som vil skje på mellomlang og lengre sikt. Da Norge er gradvis på vei ut av de sterkeste smittebegrensende tiltakene, har regieringen allerede implementert og vil trolig iverksette en rekke stimuleringsinitiativer og støtteprogrammer for å normalisere samfunnet raskest mulig. Krisepakker og gode velferdsordninger er viktige for å dempe effektene av pandemien for de som er rammet. I det følgende vil vi peke på noen tiltak som vi antar vil ha en forebyggende effekt med tanke på selvmord og villet egenskade i de risikoutsatte gruppene vi har nevnt ovenfor.

\section{Opprettholde fysisk distanse, men ikke sosial distanse}

Begrepet 'sosial distansering' er egentlig misvisende og uheldig. Det som kreves er fysisk avstand mellom mennesker, ikke sosial distanse (Reger et al., 2020). Derfor bør det satses på tiltak som hjelper folk å opprettholde

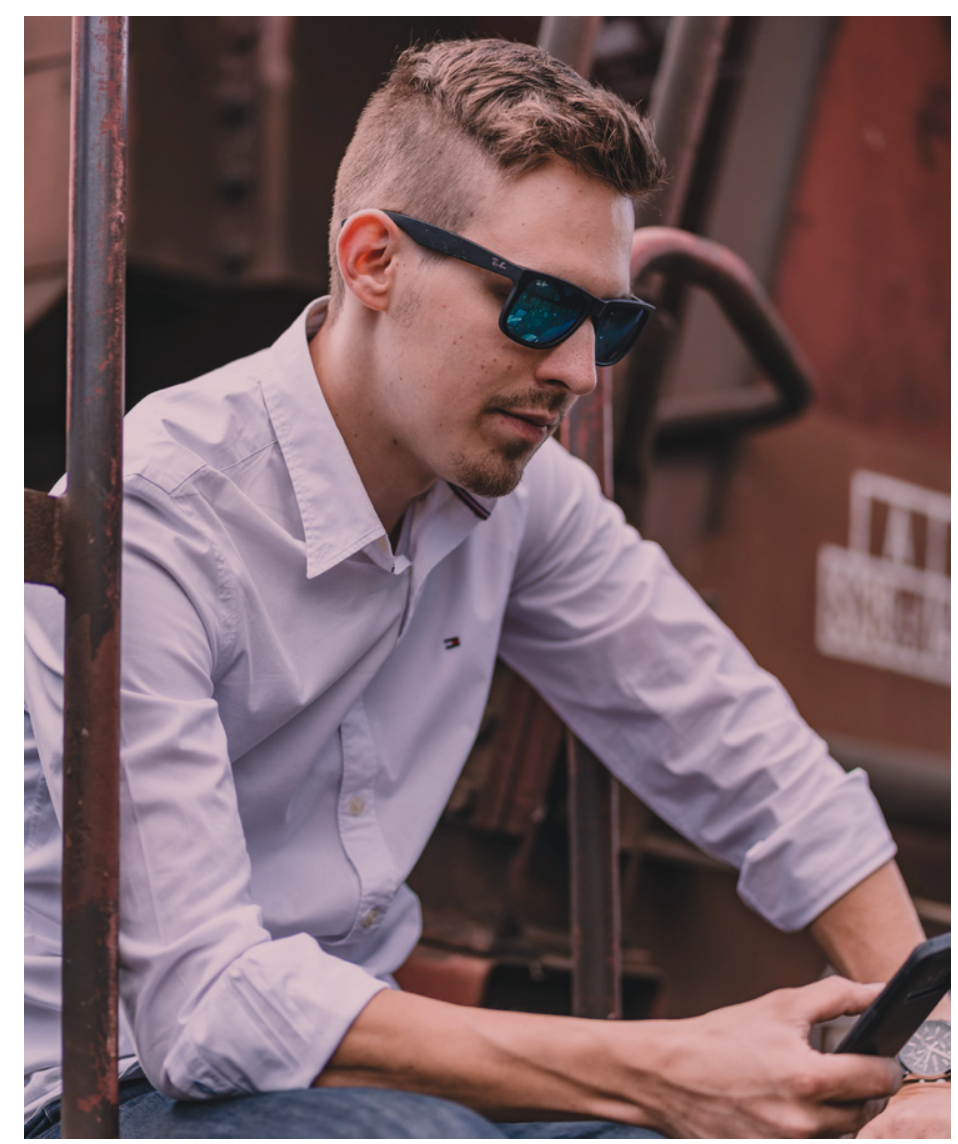

sosial kontakt og meningsfulle relasjoner på digitale flater, telefon eller andre måter. Her har mange vist stor kreativitet, kanskje særlig dem som fra før hadde velutviklede sosiale ferdigheter. Men det er særlig viktig å sørge for støtte i nærmiliøet for dem som fra før har få sosiale kontaktpunkter, som bor alene eller som er avhengig av at andre tar initiativ.

\section{Minske frykt og angst i befolkningen gjennom informasjonstiltak}

Til tross for at det fremdeles er stor usikkerhet rundt pandemiens videre utvikling, kan presis informasjon knyttet til ny kunnskap om utviklingen av covid-19 og effekten av behandling og intervensjoner bidra til å redusere frykt og angst samt stigma knyttet til viruset og sykdommen. Informasjon av typen «Råd for koronahverdagen» utgitt av Helsedirektoratet (Helsedirektoratet, 2020) kan her være nyttig.

\section{Øke tilgangen til psykiske helsetjenester}

Selvmordsraten kan øke med reduksion av behandlingstilbudet i psykisk helsevern (Hung et al., 2020), og vårt klare inntrykk er at selv 
om mange klinikere og kliniske enheter har giort et imponerende arbeid for å opprettholde virksomheten, har kapasiteten falt betydelig i den tiden pandemien hittil har vart. Over tid blir det avgiørende om spesialisthelsetienesten klarer å reetablere tilstrekkelig kapasitet både i sengeavdelinger og poliklinikker til å dekke behovet i befolkningen.

Styrke kunnskap om psykisk helse i skolen De yngste barna har allerede returnert til skolen og de øvrige vil snart følge etter. Undervisningsopplegg som fremmer barns psykiske helse og mestring har dokumentert effekt på å redusere selvmordsforsøk (Wasserman et al., 2015). Slike opplegg bør brukes mer systematisk i den norske skolen og det er dessuten viktig at skolene har strategier for å oppfange psykisk uhelse hos barn og unge og henviser til psykiske helsetjenester når det er nødvendig.

Tilby selvmordsforebygging på flere plattformer Moderne teknologi muliggiør avstandsbasert selvmordsforebygging. I tillegg til telefonbasert kontakt og videokonsultasjoner, bør ulike digitale løsninger, som \#chatsafe (https:// www.orygen.org.au/chatsafe/Resources/ International-guidelines/Norway-\%E2\%80\%93Norwegian) og nettbaserte selvhielpsressurser (f.eks. www.ifightdepression.com/no/) i økende grad videreutvikles og implementeres. Slike alternative plattformer giør mestringsressurser lettere tilgiengelig for alle som blir rammet av pandemien, og muliggiør oppfølging og tiltak for mennesker som er i risiko for selvmord.

\section{Forbedre krisetelefoner og frivillige organisasjoner}

Krisetelefoner, chat-tienester på nett og andre lavterskeltilbud er verdifulle bidrag fra frivillige organisasioner og er særlig nyttige i vanskelig tider. Disse tienester kan forholdsvis oppskaleres dersom støtte stilles til å gi kunnskap om selvmordsforebygging.

\section{Begrense tilgang til selvmordsmetoder}

I perioder som den vi er i nå, vil mange søke å skaffe seg et ekstra forråd av medikamenter for å sikre seg mot manglende tilgang. Dette representerer en separat risiko for selvmordsatferd ved forgiftning for alle aldersgrupper, men særlig for unge. Informasjonstiltak fra helsemyndighetene og apoteker til familier om behovet for trygg oppbevaring av medikamenter som kan brukes til forgiftning er et viktig tiltak, i og utenfor krisesituasjoner som den vi er i nå.

\section{Sikre ansvarlig rapportering i media}

Smitteeffekter etter medieomtale av selvmord er vel dokumentert (Niederkrotenthaler et al., 2020). Oppslag i media om selvmord i forbindelse med pandemien bør følge eksisterende retningslinjer fra pressens egne organer (World Health Organization, 2017; Norsk Redaktørforening, 2019) og bør ledsages av opplysninger om hielpetienester for personer som har selvmordstanker.

\section{Oppsummering}

Covid-19-pandemien vil medføre store belastninger og oke sannsynligheten for psykiske lidelser og selvmordsatferd for risikoutsatte grupper i befolkningen. Kanskje kan en slik krise på kort sikt føre til økt samhold og sosial integrasion i befolkningen og derigiennom en redusert forekomst av selvmord i befolkningen som helhet. Motsatt vil frykt, isolasion og sosial distansering kunne forverre psykiske lidelser og medføre okt risiko for selvmordsatferd i sårbare grupper. Over lengre tid, når og hvis de mange negative psykososiale og sosioøkonomiske effektene slår sterkere inn, vil forekomsten av selvmord kunne øke. Mye vil avhenge av hvilke forebyggende tiltak som settes inn for å redusere effektene av de faktorene vi har diskutert ovenfor.

Manus levert 12. mai 2020

\section{LITTERATUR}

Alimoradi, Z., Lin, C. Y., Broström, A., Bülow, P. H., Bajalan, Z., Griffiths, M. D., ... Pakpour, A. (2019). Internet addiction and sleep problems: A systematic review and meta-analysis. Sleep Medicine Reviews, 47, 51-61.

Amin, R., Helgesson, M., Runeson, B., Tinghög, P., Mehlum, L., Qin, P., ... Mittendorfer-Rutz, E. (2019). Suicide attempt and suicide in refugees in Sweden - a nationwide population-based cohort study. Psychological Medicine, 1-10.

Bo, H. X., Li, W., Yang, Y., Wang, Y., Zhang, Q., Cheung, T., . . Xiang, Y. (2020). Posttraumatic stress symptoms and attitude toward crisis mental health services among clinically stable patients with COVID-19 in China. Psychological Medicine, 1-7.

Calati, R., Ferrari, C., Brittner, M., Oasi, O., Olié, E., Carvalho, A. F., \& Courtet, P. (2019). Suicidal thoughts and behaviors and social isolation: A narrative review of the literature. Journal of Affective Disorders, 245, 653-667.

Douglas, P. K., Douglas, D. B., Harrigan, D. C., \& Douglas, K. M. (2009). Preparing for pandemic influenza and its aftermath: Mental health issues considered. International Journal of Emergency Mental Health, 11(3), 137-44.

Erzen, E. \& Çikrikci, Ö. (2018). The effect of loneliness on depression: A meta-analysis. International Journal of Social Psychiatry, 64(5), 427-435. 
Fladberg, K. L. (2020, 29. april). Alarmtelefonen for barn og unge: Nær 3.000 henvendelser siden 12. mars. Dagsavisen. Hentet fra https://www.dagsavisen.no/oslo/alarmtelefonen-forbarn-og-unge-ner-3-ooo-henvendelser-siden-12-mars-1.1706670.

Folkehelseinstituttet (2020). Dags- og ukerapporter om koronavirussykdom (covid-19) [Available from: https://www.fhi. no/sv/smittsomme-sykdommer/corona/dags--og-ukerapporter/ dags--og-ukerapporter-om-koronavirus/.

Haw, C., Hawton, K., Gunnell, D., \& Platt, S. (2015). Economic recession and suicidal behaviour: Possible mechanisms and ameliorating factors. International Journal of Social Psychiatry, 61(1), 73-81.

Helsedirektoratet (2020). Råd for koronahverdagen. Hentet fra https://helsenorge.no/koronavirus/rad-for-koronahverdagen?utm_source=facebook\&utm_medium=social\&utm_content=psykisk_helse_\&utm_campaign=hedir_helsedirektoratet korona-informasionskampanie\&fbclid=IwAR2 p2iLgh4NY-Rn8ih8QlSztEB-gkydX7wonbz9FpRFaVITCAzi195ac-k.

Hung, P., Busch, S. H., Shih, Y. W., McGregor, A. I., \& Wang, S (2020). Changes in community mental health services availability and suicide mortality in the US: A retrospective study. BMC Psychiatry, 20(1), 188.

Lai, I., Ma, S., Wang, Y., Cai, Z., Hu, I., Wei, N., ... Hu, S. (2020). Factors Associated With Mental Health Outcomes Among Health Care Workers Exposed to Coronavirus Disease 2019. IAMA Network Open, 3(3), E203976.

Lee, S. M., Kang, W. S., Cho, A. R., Kim, T., \& Park, I. K. (2018). Psychological impact of the 2015 MERS outbreak on hospital workers and quarantined hemodialysis patients. Comprehensive psychiatry, 87, 123-7.

Lockwood, I., Daley, D., Townsend, E., \& Sayal, K. (2017). Impulsivity and self-harm in adolescence: a systematic review. European Child \& Adolescent Psychiatry, 26(4), 387-402.

NAV. (2020). Søknader om dagpenger. Hentet fra https://www. nav.no/no/nav-og-samfunn/statistikk/flere-statistikkomrader/ relatert-informasion/soknader-om-dagpenger.

Niederkrotenthaler, T., Braun, M., Pirkis, I., Till, B., Stack, S., Sinyor, M., ... Spittal, M. (2020). Association between suicide reporting in the media and suicide: Systematic review and meta-analysis. BMI, 368, M575

Norsk Redaktorforening (2019). Slik omtaler du selvmord. Hentet fra https://www.nored.no/NR-dokumentasion/Rapporterog-veiledere/Slik-omtaler-du-selvmord?fbclid=IwAR36O1CgoNfR HoxUhOqNDtvwrnuAFqcHeuGP4/rbyıIA-uWQIhWMzlzeUrw.

Puzo, Q., Mehlum, L., \& Qin, P. (2017). Suicide among immigrant population in Norway: A national register-based study. Acta Psychiatrica Scandinavica, 135(6), 584-592.

Reger, M. A., Stanley, I. H., Joiner, T. E. (2020). Suicide Mortality and Coronavirus Disease 2019-A Perfect Storm? IAMA Psychiatry, 10. april 2020.

Sani, G., Janiri, D., Di Nicola, M., Janiri, L., Ferretti, S., \& Chieffo, D. (2020). Mental health during and after the COVID-19 emergency in Italy. Psychiatry and Clinical Neurosciences, 04. april 2020 .

Sim, K., \& Chua, H. C. (2004). The psychological impact of SARS: A matter of heart and mind. CMAT: Canadian Medical Assiciation Journal = Journat De L'Association Medical Canadienne, 170(5), 811-812.

Wasserman, D., Hoven, C. W., Wasserman, C., Wall, M., Eisenberg, R., Hadlaczky, G., ... Kahn, I.-P. (2015). School-based suicide prevention programmes: The SEYLE cluster-randomised controlled trial. The Lancet, 385(9977), 1536-1544.
Wasserman, I. M. (1992). The Impact of Epidemic, War, Prohibition and Media on Suicide: United States, 1910-1920. Suicide \& Life-Threatening Behavior, 22(2), 240-254.

World Health Organization. (2017). Preventing suicide: a resource for media professionals - update 2017 . Hentet fra https://www.who.int/mental_health/suicide-prevention/ resource_booklet_2017/en/.

Yip, P. S., Cheung, Y. T., Chau, P. H., \& Law, Y. W. (2010). The Impact of Epidemic Outbreak: The Case of Severe Acute Respiratory Syndrome (SARS) and Suicide Among Older Adults in Hong Kong. Crisis: The Journal of Crisis Intervention and Suicide Prevention, 31(2), 86-92.

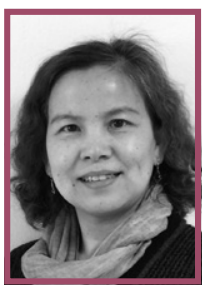

PING QIN er dr.med., professor, spesialist i psykiatrisk epidemiologi og suicidologi ved Nasjonalt senter for selvmordsforskning og -forebygging, Institutt for klinisk medisin,

Universitetet i Oslo.

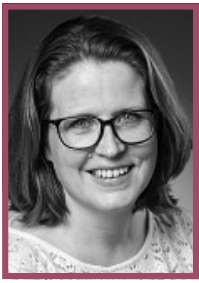

\section{INGUNN LEGARD er} prosjektkoordinator ved Nasjonalt senter for selvmordsforskning og -forebygging, Institutt for klinisk medisin, Universitetet i Oslo.

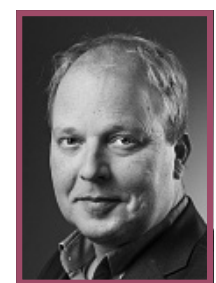

FREDRIK A. WALBY er forsker, psykologspesialist ved Nasjonalt senter for selvmordsforskning og -forebygging, Institutt for klinisk medisin, Universitetet i Oslo.

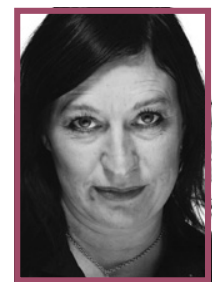

\section{ANITA JOHANNA TØRMOEN er} ph.d., førsteamanuensis og leder av utdanningsvirksomheten ved Nasjonalt senter for selvmordsforskning og -forebygging, Institutt for klinisk medisin, Universitetet i Oslo.

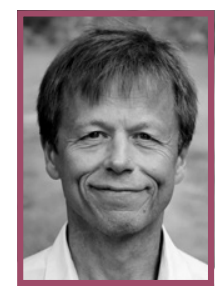

LARS MEHLUM er dr.med., professor i psykiatri og suicidologi, senterleder ved Nasjonalt senter for selvmordsforskning og -forebygging, Institutt for klinisk medisin, Universitetet i Oslo. 